\title{
THE ROLE OF ASEAN EXCHANGE RATE UNIT (AERU) FOR ASEAN-5 MONETARY INTEGRATION: AN OPTIMUM CURRENCY AREA CRITERIA
}

\author{
Dimas Bagus Wiranata Kusuma, Syed Mohammed Abud Ashif, \\ Ali Musa Harahap, Muhammad Alam Omarsyah ${ }^{1}$
}

\begin{abstract}
The idea for regional monetary integration is grounded by the process of convergence theory within the member states. The paper analyses the possibility of monetary union in ASEAN-5 countries, Indonesia, Malaysia, Philippines, Thailand, and Singapore. In terms of volatility, by using nominal deviation indicator assessment, the ASEAN-5 currencies are suggested to peg their national currencies into Yuan since it empirically brings the lowest level of volatility, both during normal and crisis periods. Therefore, Yuan could be proposed as the anchor currency for ASEAN-5 countries. Moreover, valuing the AERU in terms of a weighed average of Yuan is important to determine which countries are considered to be an Optimum Currency Area (OCA). The results statistically suggest that all ASEAN-5 countries could be grouped as OCA according to exchange rate stability criterion.
\end{abstract}

Keywords : Optimum Currency Area, AERU, ASEAN-5, Exchange Rate Stability

JEL Classification : D81, E52, F15, F36

\footnotetext{
1 Kulliyyah of Economics and Management Sciences, International Islamic University Malaysia; dimas economist@yahoo.com (+60102906105), abudasif@gmail.com (+60-182893070), aliemharahap@yahoo.com (+60-172905529), nastfrom midle@yahoo.com (+60-173984722).
} 


\section{INTRODUCTION}

The possibility of creating an ASEAN currency unit (ACU) is a further step of the ASEAN "vision 2020"2. In May 2006, Hyderabad, India, the finance ministers of ASEAN+3 agreed to pursue a study on creating regional monetary units (RMUs) at the ASEAN+3 Finance Ministers' meeting. They urged to take steps to coordinate their currencies in a way to produce a common regional currency similar to the Euro.

The regional financial crises in 1997/1998 eroded the credibility of unilateral fixed exchange rate in ASEAN and then renewed calls for greater monetary integration and then ultimately enhanced regional exchange rate stability ${ }^{3}$. With respect to exchange rate stability, Euro member countries had adopted the Exchange Rate Mechanism (ERM) or European Monetary System (EMS) over the previous two years prior involvement in Euro. Under such mechanism, participating countries are able to maintain their exchange rate movement within bilateral limits of plus minus 2.25 percent. The table below shows some bilateral nominal

\begin{tabular}{|c|c|c|c|c|c|}
\hline \multicolumn{6}{|c|}{$\begin{array}{l}\text { Table } 1 . \\
\text { Nominal Exchange Rate against ERM Currencies,1974-1990* }\end{array}$} \\
\hline Currency/Country & $\begin{array}{c}\text { Pre-EMS } \\
\text { Period } \\
(1974-1978)\end{array}$ & $\begin{array}{l}\text { Recession Period } \\
(1979-1983)\end{array}$ & $\begin{array}{l}\text { SEA Period }^{4} \\
(19841986)\end{array}$ & $\begin{array}{l}\text { Post-EMS } \\
\text { Period } \\
(1987-1990)\end{array}$ & $\begin{array}{c}\text { Post-SEA Period } \\
\text { Average } \\
(1979-1990)\end{array}$ \\
\hline Belgium/Luxembourg franc & 1.2 & 1.3 & 0.6 & 0.4 & 0.9 \\
\hline Danish crown & 1.4 & 1.0 & 0.5 & 0.5 & 0.8 \\
\hline German DM & 1.5 & 1.0 & 0.5 & 0.5 & 0.8 \\
\hline Greek drachma & 1.8 & 2.3 & 2.5 & 0.7 & 2.1 \\
\hline Portuguese escudo & 3.0 & 2.1 & 0.8 & 1.1 & 1.8 \\
\hline French franc & 1.9 & 1.1 & 0.7 & 0.5 & 0.7 \\
\hline Irish punt & 2.0 & 0.7 & 1.2 & 0.5 & 1.0 \\
\hline Italia lira & 2.2 & 1.0 & 0.9 & 0.6 & 0.8 \\
\hline Dutch guilder & 1.0 & 0.8 & 0.6 & 0.3 & 0.5 \\
\hline Spanish peseta & 2.8 & 2.0 & 1.1 & 0.5 & 1.7 \\
\hline UK pound & 2.2 & 2.6 & 2.4 & 1.9 & 2.4 \\
\hline EC mean & 1.7 & 0.7 & 0.5 & 0.4 & 0.4 \\
\hline U.S. dollar & 2.2 & 2.5 & 2.9 & 2.7 & 2.7 \\
\hline Japanese yen & 2.3 & 2.7 & 2.0 & 1.9 & 2.5 \\
\hline
\end{tabular}

2 The ASEAN Heads of States/Governments adopted the Declaration of ASEAN Concord II (Bali Concord II) in 2003, which establishes an ASEAN Community by 2020. ASEAN community will reinforce ASEAN's centrality and role as the driving force in charting the evolving regional architecture. ASEAN vision 2020 was declared in Kuala Lumpur in December 1997 that decided to transform ASEAN into a stable, prosperous, and highly competitive region with equitable economic development, and reduced poverty and socio-economy disparities.

3 According to World bank (2000), cost recapitulation for crises over GDP were recorded as follows: Indonesia (58\% GDP), Malaysia (10\%GDP), Thailand (30\%GDP), and Korea (10\%GDP).

4 Denotes Single European Act which specifically targeted regional issues, recognizing that redistribution of economic resources from richer to poorer areas of the EC was essential in order to achieve harmonious economic integration. 
exchange rates against ERM currencies. The results suggested over period 1974 to 1990, all joined countries majority are able to keep their currencies volatility less than 2.5 percent, and in average European Countries became less variable against one another, as well as, against US dollar and the Japanese Yen.

The question remains is whether ASEAN is ready to establish such monetary union? Such question is relevant when considering the feasibility of ASEAN Currency Unit measurement, which requires the region to satisfy the theory of optimum currency Area (OCA). The definition of this theory is ascribed from the presence of economic convergence criteria of each member state's economy as an entry condition for union establishment. Later, convergence criteria was ratified by Maastricht Treaty in article 109j, which defines some macroeconomic indicators as convergence measurements, namely; price stability, soundness and sustainability of public finances, exchange rate stability, and convergence in long-term interest rates. Therefore, this study focuses on one parts of above mentioned convergence criteria, namely exchange rate stability achievement.

The current crisis in Eurozone, it is not an amazing result nor unprecedented. The basic problem is because of the relaxation on their entrance exams in 1998. Therefore, we may say that the entrance criteria have very little to do with economics, and very much with the politics. During the 1990s, the governments of most EU-countries had made a strong political commitment to go ahead with monetary union. By 1999, large number of countries committed to the monetary union would fail the entrance criteria, and only a few countries would succeed. So politics prevailed and the annoying Maastricht numbers were set aside - which was the right decision and conclusively showed that the Maastricht convergence criteria are irrelevant. Some evidences are denoted by comparing state's participation criteria fulfillment conditions at the end of 1996 and 1997 when they became subject to assessment, as follows:

\begin{tabular}{|c|c|c|c|c|c|c|c|c|c|c|}
\hline \multicolumn{11}{|c|}{$\begin{array}{l}\text { Table } 2 . \\
\text { EMU Participation Criteria and the Fulfillment Conditions }\end{array}$} \\
\hline \multirow{2}{*}{$\begin{array}{c}\text { Country } \\
\text { Year }\end{array}$} & \multicolumn{2}{|c|}{$\begin{array}{l}\text { Consumer price } \\
\text { (Inflation rate) }\end{array}$} & \multicolumn{2}{|c|}{$\begin{array}{l}\text { Long term } \\
\text { interest rate }\end{array}$} & \multicolumn{2}{|c|}{$\begin{array}{l}\text { Government } \\
\text { fiscal deficit/ } \\
\text { nominal GDP }\end{array}$} & \multicolumn{2}{|c|}{$\begin{array}{l}\text { Government } \\
\text { debt balancel } \\
\text { nominal GDP }\end{array}$} & \multicolumn{2}{|c|}{$\begin{array}{l}\text { Exchange rate } \\
\text { stability }\end{array}$} \\
\hline & 1996 & 1997 & 1996 & 1997 & 1996 & 1997 & 1996 & 1997 & 1996 & 1997 \\
\hline $\begin{array}{l}\text { Participation } \\
\text { criteria }\end{array}$ & 2.6 & 2.7 & 9.1 & 7.8 & 3.0 & 3.0 & 60.0 & 60.0 & V & V \\
\hline Austria & 1.8 & 1.1 & 6.3 & 5.6 & 4.0 & 2.5 & 69.5 & 66.1 & V & V \\
\hline Belgium & 1.8 & 1.4 & 6.5 & 5.7 & 3.2 & 2.1 & 126.9 & 122.2 & V & V \\
\hline Denmark & 2.1 & 1.9 & 7.2 & 6.2 & 0.7 & -0.7 & 70.6 & 65.1 & V & V \\
\hline Finland & 1.1 & 1.3 & 7.1 & 5.9 & 3.3 & 0.9 & 57.6 & 55.8 & 0 & V \\
\hline France & 2.1 & 1.2 & 6.3 & 5.5 & 4.1 & 3.0 & 55.7 & 58.0 & V & V \\
\hline Germany & 1.2 & 1.4 & 6.2 & 5.6 & 3.4 & 2.7 & 60.4 & 61.3 & V & V \\
\hline Greece & 7.9 & 5.2 & 14.4 & 9.8 & 7.5 & 4.0 & 111.6 & 108.7 & $x$ & $x$ \\
\hline Ireland & 2.2 & 1.2 & 7.3 & 6.2 & 0.4 & 0.9 & 72.7 & 66.3 & V & V \\
\hline
\end{tabular}




\begin{tabular}{|c|c|c|c|c|c|c|c|c|c|c|}
\hline \multicolumn{11}{|c|}{$\begin{array}{l}\text { Table } 2 . \\
\text { EMU Participation Criteria and the Fulfillment Conditions }\end{array}$} \\
\hline \multirow{2}{*}{$\begin{array}{c}\text { Country } \\
\text { Year }\end{array}$} & \multicolumn{2}{|c|}{$\begin{array}{l}\text { Consumer price } \\
\text { (Inflation rate) }\end{array}$} & \multicolumn{2}{|c|}{$\begin{array}{l}\text { Long term } \\
\text { interest rate }\end{array}$} & \multicolumn{2}{|c|}{$\begin{array}{l}\text { Government } \\
\text { fiscal deficit/ } \\
\text { nominal GDP }\end{array}$} & \multicolumn{2}{|c|}{$\begin{array}{l}\text { Government } \\
\text { debt balance/ } \\
\text { nominal GDP }\end{array}$} & \multicolumn{2}{|c|}{$\begin{array}{l}\text { Exchange rate } \\
\text { stability }\end{array}$} \\
\hline & 1996 & 1997 & 1996 & 1997 & 1996 & 1997 & 1996 & 1997 & 1996 & 1997 \\
\hline Italy & 4.0 & 1.8 & 9.4 & 6.7 & 6.7 & 2.7 & 124.0 & 121.6 & 0 & V \\
\hline Luxembourg & 1.2 & 1.4 & 6.3 & 5.6 & -2.5 & -1.7 & 6.6 & 6.7 & V & V \\
\hline Netherlands & 1.4 & 1.8 & 6.2 & 5.5 & 2.3 & 1.4 & 77.2 & 72.1 & V & V \\
\hline Portugal & 2.9 & 1.8 & 8.6 & 6.2 & 3.2 & 2.5 & 65.0 & 62.0 & V & V \\
\hline Spain & 3.6 & 1.8 & 8.7 & 6.3 & 4.6 & 2.6 & 70.1 & 68.8 & V & V \\
\hline Sweden & 0.8 & 1.9 & 8.0 & 6.5 & 3.5 & 0.8 & 76.7 & 76.6 & $x$ & $x$ \\
\hline UK & 2.5 & 1.8 & 7.9 & 7.0 & 4.8 & 1.9 & 54.7 & 53.4 & $x$ & $x$ \\
\hline
\end{tabular}

For ASEAN countries, the monetary union is theoretically still a long processsince the monetary integration shall be undertaken in a gradual basis. Referring Bayoumi et al (2000), the dissimilarity of the level of economic development and monetary system is the main obstacle to support economic and monetary integration. The similarity of past macroeconomic policies, stage of economic development and financial systems would increase the integration possibility, thereforethe proposed of ASEAN-5 countries are selected into analysis as the initial step to form a currency union in ASEAN region. This kind of approach had been tried by Europe when they established a union whereas the European Monetary Union (EMU) invited only four of its major members 5 . They were included as they have comparable population, size, resources, and economies (Day and Herbig, 1995).

In the context of ASEAN-5, these group countries make up over 72 percent in terms of total population inhabitants compared to ASEAN $-10^{6}$. Meanwhile, the degree of economic development in ASEAN-5 is homogeneous and dominant, particularly, if we discern on their trade volume of around 92 percent of the total ASEAN-10 volume of trade. Size of GDP and international reserve posit a tremendous portion for affecting economic policies in the region as almost 96 percent in 2008. In summary, the ability of ASEAN-5 to work together based on above common indicators is apparent and it would sustain the common goal of a successful regional economic cooperation, finally benefiting gradually all participating economies as well as peripheral economies in the region.

5 During the 1950s (initial stage establishment of the European Union), three regional European organizations were form: the European Coal and Steel Community (ECSC), the European Economic Community (EEC), and the European Atomic Energy Community (Euratom). Initially, six states were involved in the formation of these organizations: Belgium, France, Italy, Luxembourg, the Netherlands, and West Germany (the German Federal Republic) where these countries have similar economic stage of development.

6 ASEAN-10 denotes Brunei Darussalam, Cambodia, Indonesia, Laos, Malaysia, Myanmar, the Philippines, Singapore, Thailand, Vietnam. 
Table 3

Key Indicators of Selected ASEAN Countries

\begin{tabular}{|c|c|c|c|c|c|}
\hline Country & Year & $\begin{array}{l}\text { Population } \\
\text { (Million) }\end{array}$ & $\begin{array}{l}\text { Volume of Trade } \\
\text { (US\$ Million) }\end{array}$ & $\begin{array}{l}\text { GDP Nominal } \\
\text { (US\$ Million) }\end{array}$ & $\begin{array}{c}\text { International } \\
\text { Reserve } \\
\text { (US\$ Million) }\end{array}$ \\
\hline \multirow{3}{*}{ Brunei } & 2004 & 0.36 & 6493.28 & 5484.697349 & 488.89 \\
\hline & 2006 & 0.38 & $N / A$ & $\mathrm{~N} / \mathrm{A}$ & 513.57 \\
\hline & 2008 & 0.39 & $\mathrm{~N} / \mathrm{A}$ & N/A & 748.72 \\
\hline \multirow{3}{*}{ Cambodia } & 2004 & 13.65 & 5991.29 & 5337.47 & 943.21 \\
\hline & 2006 & 14.09 & 8549.18 & 7274.50 & 1157.25 \\
\hline & 2008 & 14.56 & N/A & N/A & 2291.55 \\
\hline \multirow{3}{*}{ Indonesia } & 2004 & 216.44 & 127172.50 & 256837.28 & 34952.50 \\
\hline & 2006 & 221.95 & 182273.80 & 364570.73 & 41103.10 \\
\hline & 2008 & 227.35 & 277407 & 510779.50 & 49596.70 \\
\hline \multirow{3}{*}{ Laos } & 2004 & 5.78 & 1076.06 & 2511.95 & 223.25 \\
\hline & 2006 & 5.98 & 1941.53 & 3485.00 & 328.43 \\
\hline & 2008 & 6.21 & $\mathrm{~N} / \mathrm{A}$ & N/A & $\mathrm{N} / \mathrm{A}$ \\
\hline \multirow{3}{*}{ Malaysia } & 2004 & 25.17 & 231042.63 & 124749.47 & 65881.10 \\
\hline & 2006 & 26.10 & 291450.80 & 156408.90 & 82132.30 \\
\hline & 2008 & 27.01 & 372880.81 & 222049.98 & 91148.80 \\
\hline \multirow{3}{*}{ Myanmar } & 2004 & 48.00 & 4581.28 & 1580.06 & 672.134 \\
\hline & 2006 & 48.72 & 7133.64 & $\mathrm{~N} / \mathrm{A}$ & 1235.61 \\
\hline & 2008 & 49.56 & 11305.42 & $\mathrm{~N} / \mathrm{A}$ & $\mathrm{N} / \mathrm{A}$ \\
\hline \multirow{3}{*}{ Philippines } & 2004 & 83.91 & 82039.04 & 86930.02 & 13116.30 \\
\hline & 2006 & 87.10 & 101450.08 & 117566.44 & 20025.40 \\
\hline & 2008 & 90.35 & 108823.01 & 168580.26 & 33192.90 \\
\hline \multirow{3}{*}{ Singapore } & 2004 & 4.20 & 362382.04 & 109668.50 & 112579.00 \\
\hline & 2006 & 4.36 & 510080.99 & 139177.30 & 136260.00 \\
\hline & 2008 & 4.62 & 655676.88 & 181938.84 & 174193.00 \\
\hline \multirow{3}{*}{ Thailand } & 2004 & 65.28 & 190838.68 & 161688.26 & 48664.00 \\
\hline & 2006 & 66.51 & 259175.33 & 206247.03 & 65291.40 \\
\hline & 2008 & 67.39 & 351200.27 & 273247.92 & 108661.00 \\
\hline \multirow{3}{*}{ Vietnam } & 2004 & 83.02 & 58453.80 & 4542.79 & 7041.46 \\
\hline & 2006 & 85.10 & 84015.00 & 6091.33 & 13384.10 \\
\hline & 2008 & 87.10 & 140231.00 & $\mathrm{~N} / \mathrm{A}$ & 23890.30 \\
\hline
\end{tabular}

\begin{tabular}{c|c|c|c|c|c} 
Country & Year & $\begin{array}{c}\text { Total } \\
\text { Population } \\
\text { (Million) }\end{array}$ & $\begin{array}{c}\text { Total Volume of Trade } \\
\text { (US\$ Million) }\end{array}$ & $\begin{array}{c}\text { Total GDP Nominal } \\
\text { (US\$ Million) }\end{array}$ & $\begin{array}{c}\text { Total International } \\
\text { Reserve } \\
\text { (US\$ Million) }\end{array}$ \\
\hline \multirow{3}{*}{ ASEAN-5 } & 2004 & 395.01 & 993474.91 & 739873.56 & 275192.90 \\
\cline { 2 - 6 } & 2006 & 406.02 & 1344431.02 & 983970.42 & 344812.20 \\
\cline { 2 - 6 } & 2008 & 416.71 & 1765987.98 & 1356596.53 & 456792.40
\end{tabular}

\begin{tabular}{c|c|c|c|c|c|} 
Country & Year & $\begin{array}{c}\text { Total } \\
\text { Population } \\
\text { (Million) }\end{array}$ & $\begin{array}{c}\text { Total Volume of Trade } \\
\text { (US\$ Million) }\end{array}$ & $\begin{array}{c}\text { Total GDP Nominal } \\
\text { (US\$ Million) }\end{array}$ & $\begin{array}{c}\text { Total International } \\
\text { Reserve } \\
\text { (US\$ Million) }\end{array}$ \\
\hline \multirow{3}{*}{ ASEAN-10 } & 2004 & 545.82 & 1070070.62 & 759330.528 & 284561.84 \\
\cline { 2 - 6 } & 2006 & 560.29 & 1446070.37 & N/A & 361431.16 \\
\cline { 2 - 6 } & 2008 & 574.53 & 1917524.41 & N/A & 483722.97
\end{tabular}




\begin{tabular}{|c|c|c|c|c|c|}
\hline Country & Year & $\begin{array}{c}\text { Total } \\
\text { Population } \\
\text { (Million) }\end{array}$ & $\begin{array}{l}\text { Total Volume of Trade } \\
\text { (US\$ Million) }\end{array}$ & $\begin{array}{l}\text { Total GDP Nominal } \\
\text { (US\$ Million) }\end{array}$ & $\begin{array}{c}\text { Total Internationa } \\
\text { Reserve } \\
\text { (US\$ Million) }\end{array}$ \\
\hline \multirow{3}{*}{ ASEAN-5 } & 2004 & 72.37 & 92.84 & 97.44 & 96.71 \\
\hline & 2006 & 72.47 & 92.97 & $\mathrm{~N} / \mathrm{A}$ & 95.40 \\
\hline & 2008 & 72.53 & 92.10 & $\mathrm{~N} / \mathrm{A}$ & 94.43 \\
\hline
\end{tabular}

Several researches have been carried out regarding the reliability and the possibility of ASEAN-5 towards enhanced economic and monetary unification. McAleer and Nam (2005), highlight suitability of establishing a common currency area for ASEAN-5 from the perspective of contagion. They find out (1) contagion was present between all country pairs in ASEAN-5; an indication that the degree of correlation among ASEAN-5 economies had increased during the Asian financial crisis, (2) closer monetary co-operation among ASEAN-5 economies would be feasible. In addition, Ramayandi (2005) discusses on issues and prospects of ASEAN monetary union. In other words, ASEAN-5 is found to be suitable for a monetary co-operation due to their relative symmetrical economic shocks and trade patterns.

Finally, monetary union or integration in ASEAN-5 countries is an important step towards economic integration. It could be implemented if ASEAN-5 countries have pursued policy coordination on their exchange rates policies. On this paper, possible research questions are highlighted to address the ASEAN-5 monetary union into existence, first, how to develop the hypothetical currency unit in ASEAN-5 countries, called ASEAN Exchange Rate Unit (AERU) under normal and crisis periods?; second, is AERU stable by pegging its value fix against currency baskets (US\$-Euro-Yen-Yuan, US\$-Euro-Yen, US\$-Euro), and Individual peg currency (US\$, Euro, Yen, Yuan, and Singapore Dollar) under normal and crisis periods?; and third, who are the proposed members to form Optimum Currency Area in ASEAN-5 economies?

This paper is organized as follows; section two covers the theoretical review. Section three discusses the data and methodology including the calculation steps on AERU, while section four presents the result and analysis. Conclusion and policy recommendation is presented on the last section and will close the presentation.

\section{THEORY}

\section{The Theory of Monetary Union and the Convergence Theory}

The modern and comprehensive thought regarding OCA theory was initially explained by Robert Mundell in his seminar paper entitled "A Theory of Optimum Currency Area" in 1961. It defines as the optimal geographic domain of a single currency, or of several currencies, whose exchange rates are irrevocably pegged and might be unified. Later in the latest decade, this idea was developed whereas the member states must fulfill the requirements of OCA 
characteristics. Frankel and Rose (1998) precisely stated that OCA characteristics could be satisfied endogenously. In other words, a group of countries could not meet one or more OCA criteria ex-ante, but ex-post.

As OCA closes into the integration idea, Warjiyo (2004) explicitly compares the cost and benefit reaped by joining monetary union. According to Table 4, the main benefit of unification would be the symmetric response towards the onset of shocks. As the economic convergence is achieved, the cost and the threat faced by the country members can be aptly reduced. Meanwhile, the cost is related with the short term adjustment process towards convergence policy. Once the member states can structurally remove the process by fulfilling the stipulated requirement by union, the cost will be gradually eliminated.

\begin{tabular}{l|l}
\multicolumn{1}{c}{ The Benefit and the Cost of Economic Integration } \\
\multicolumn{1}{c}{ Benefit } & \multicolumn{1}{c}{ Cost } \\
\hline $\begin{array}{l}\text { Micro efficiency increases due to extending money } \\
\text { utility throughout region. }\end{array}$ & $\begin{array}{l}\text { Some weaknesses on micro level especially on the } \\
\text { first level of integration, namely different policy } \\
\text { preferences. }\end{array}$ \\
\hline $\begin{array}{l}\text { Macro stability recovery and development due to } \\
\text { price stability and fund access that is bigger than } \\
\text { financial integration. }\end{array}$ & $\begin{array}{l}\text { Limited choice of policy instrument to stabilize macro } \\
\text { economy (relinquishing its national monetary policy). }\end{array}$ \\
\hline $\begin{array}{l}\text { Policy coordination is more effective as the similarity } \\
\text { in shocks, extended flexibility in real sector, resembling } \\
\text { in price level determination. }\end{array}$ & $\begin{array}{l}\text { Discipline problem, the ability of member countries } \\
\text { obey the tractate prescription. }\end{array}$ \\
\begin{tabular}{l} 
Source : Warjiyo (2004) \\
\hline
\end{tabular}
\end{tabular}

The criteria singled out by the "old" OCA theory share a common rationale: by joining a monetary union (MU), a country gives up the possibility of adjusting its nominal exchange rate in response to macroeconomic shocks. The lesser the need for an economy to adjust the nominal exchange rate, the lesser the cost of joining a monetary union. While the "old" OCA theory operates in a "reduction of damages" perspectives, the "new" theory weighs the benefits of OCA membership against its costs. Under the "new" theory, the exchange rates will converge as an outcome, rather than a prerequisite of an OCA membership.

\section{The Rational for Monetary Union}

The primary aim for establishing the monetary union is exchange rate stability. Yuen (1999) illustrates that the creation of the European Monetary System (EMS) was a response to the external and internal monetary instability of the late 1970s, and the constant feature of the EMS 
was the quest for stability. In addition, according to Gros and Thygesen (1998), the increasingly tight management of the exchange rate mechanism led to a reduction in the external element of monetary instability to about one-quarter by 1990 in the EU.

According to Mundell (1961), the presence of monetary union would bring out economies of scale during the implementation period.It is because, first, when a small country fixes its currency to that of a larger country with an acceptable exchange rate fluctuation, it sets the course for the rest of its macroeconomic policies so that leads to move towards convergence trajectory. Second, the more countries join a currency area, the smaller the proportion to its output of any internal or external disturbance. Third, because money is a unit of account, there are economies of information and convenience in currency unions, and consequently the more countries that join a currency area, the more efficient it will be.

Another objective of proposing monetary union is to strengthen monetary policy coordination by setting some member's currency being pegged into the same basket of currency. Kuroda and Kawai (2002) point out that the creation of Asian Currency Unit (ACU) is likely to act as a statistical indicator summarizing the collective movement of Asian Currencies. This would enable the participating countries to stabilize their exchange rates against the ACU basket and improve the understanding for monetary and exchange rate policy coordination. Kawai, Ogawa, and Ito (2004) suggest that first the monetary Authorities of Asian countries should discuss the exchange rate issue as a part of their surveillance process. The exchange rates of these currencies are linked by terms of trade and competitive prices. Ogawa, Kawasaki and Ito (2002) pointed out possible failure on coordination in choosing an exchange rate system and policy if one country member choosesto peg their currency to USD, since it may has an adverse price effects.

\section{ASEAN-5 Exchange Rate Regimes}

The Asian currency crisis taught us that the various arrangements of currency regimes would induce coordination failure and finally endanger intra-regional exchange rate stability within the region. Ogawa and Yoshimi $(2007,2008)$ used the methodology of Frankel and Wei (1994) to investigate actual exchange rate systems and policies conducted by the monetary Authorities of East Asian countries during a period from 1999 to 2007. The study empirically examines what linkage trends each ASEAN-5 currency actually has with three major currencies: the US, the euro, and the Japanese yen.

By taking a closer look of above description, we conclude that the ASEAN-5 has a variety of linkages with their major currencies. Under the OCA theory, such condition might reflect different economic interests across the economies. 


\begin{tabular}{|c|c|c|c|c|}
\hline \multicolumn{5}{|c|}{$\begin{array}{l}\text { Table } 5 \text {. } \\
\text { Linkage of ASEAN - } 5 \text { Currencies to Selected Major Currencies }\end{array}$} \\
\hline Period & USD & Euro & Japanese Yen & Adj. $R^{2}$ \\
\hline Full sample (Indonesia Rupiah) & $0.9256^{* * *}(0.0325)$ & $\begin{array}{r}0.0993 \\
(0.0623)\end{array}$ & $0.0664^{* *}(0.0269)$ & 0.414 \\
\hline Full Sample (Malaysia Ringgit) & $0.9431^{* * *}(0.0099)$ & $\begin{array}{r}0.1397^{* * *} \\
(0.0190)\end{array}$ & $0.0003(0.0082)$ & 0.880 \\
\hline Full Sample (Philippine Peso) & $0.9096^{\star * *}(0.0215)$ & $\begin{array}{c}0.1798^{* * *} \\
(0.0413)\end{array}$ & $0.0399^{* *}(0.0178)$ & 0.607 \\
\hline Full Sample (Singapore Dollar) & $0.7156^{\star * *}(0.0108)$ & $\begin{array}{r}0.2571^{* * *} \\
(0.0207)\end{array}$ & $0.1142^{\star \star *}(0.0089)$ & 0.823 \\
\hline Full Sample (Thailand Baht) & $0.8045^{\star * *}(0.0201)$ & $\begin{array}{r}0.1375^{\star * *} \\
(0.0386)\end{array}$ & $0.1234^{* * *}(0.0166)$ & 0.614 \\
\hline
\end{tabular}

\section{Classification of ASEAN-5 Economies using Clustering Approach}

Clustering analysis is a multivariate technique to group research objects based on its characteristics, and provides a homogenous cluster. In the context of monetary union, such approach can be used to estimate which pairs of countries fulfill the OCA properties.

Falianty (2005) investigates the feasibility of forming currency union in ASEAN-5 countries by utilizing clustering method. The results show that there are two clusters (groups) that exist, namely group 1: Indonesia and the Philippines, and group 2: Malaysia, Singapore and Thailand. She suggested the currency union is optimum for Singapore, Malaysia, and Thailand. The results strengthen the conclusion that Indonesia and the Philippines are fall behind the OCA cluster in ASEAN-5.

In addition, Achsani (2010) was testing the feasibility of ASEAN+3 to form a single currency by undertaking OCA and clustering approach. By using the OCA index, the results present that the Singapore dollar is the most stable currency with the lowest OCA index relative to Malaysian ringgit, Thailand baht, Philippines peso, and Indonesian rupiah. If the ASEAN-5 will establish a single currency, the process should start with integrating Singaporean dollar and Malaysian ringgit and then followed by Thailand baht and Philippines peso. The OCA indices for Indonesia rupiah are extremely higher than the other countries, indicating difficulties to join directly the single currency.

On the other hand, the findings of the hierarchical clustering consider two consecutive process; first currency unification includes Singapore and Malaysia, and second, currency unification Thailand and the Philippines. This also highilights the IDR is inappropriate in joining the single currency due to its high dissimilarity with other currencies in the region. 


\section{METHODOLOGY}

\section{Data and Variables}

ASEAN-5 countries are seeking the optimal framework in order to reach the ultimate goal of unification, namely the ASEAN-5 monetary union. Three possible basket scenarios are proposed to adopt, (1) the Dollar, Euro, and Yen (DEY) ${ }^{7}$ and ASEAN Exchange rate Unit (AERU) ${ }^{8}$, (2) a currency basket composed of ASEAN-5 currencies (AERU), (3) or a strategy of regional monetary integration could make use of both kinds of baskets (Kawai, Ogawa, and Ito 2004).

To gain the benefit of AERU in fostering greater intra-regional exchange rate stability, there are five pertinent issues addressed throughout this chapter, particularly associated with the methodology applied to form an AERU hypothetical index and also index for surveillance purposes. First is determining AERU weights; second is calculating the benchmark exchange rate for each ASEAN-5 currency in terms of proposed currency basket; third is calculating the anchor for ASEAN-5 monetary union; fourth is measuring the volatility performance over numerous AERU arrangements; and fifth is assessment of participation in AERU based on ERM II9.

This research utilizes the following economic variables in order to form an optimum currency area in ASEAN-5 countries:

1. Trade volume (in million dollars) which consists of the volume of export and import. This variable is based on each trade direction across ASEAN- $5^{10}$ countries. In addition, the trade volume is used to compute the weigh of each currency in the basket for calculating the AERU, both in normal or crisis period. The trade direction also accounts for the trade volume between ASEAN-5 countries with some developed nations, such as US, European Union"11, Japan, and China'12. The data span from 2004 to 2010 on yearly basis.

2. Nominal GDP (in million dollars) of each ASEAN-5 countries. This variabelis used to calculate the weigh of each observable currency in the basket, both in normal and crisis period. The data spans from 2004 to 2010 on yearly basis.

3. GDP measured at Purchasing power parity (in million dollars) of each ASEAN-5 countries, and used as one of economic criteria to calculate the weigh of each observable currency in the basket. The data spans from 2004 to 2010 on yearly basis.

7 DEY is a common basket based on own trade pattern.

8 AERU grouped as individual-country baskets because it is based on common currency basket weights within the region (Castel et all, 2007).

9 The Exchange Rate Mechanism (ERM II) was set up on 1 January 1999 as a successor to ERM to ensure that exchange rate fluctuations between the euro and other EU currencies do not disrupt economic stability within the single market, and to help non euro-area countries prepare themselves for participation in the euro area. The convergence criterion on exchange rate stability requires participation in ERM II.

10 ASEAN-5 countries denotes for Indonesia, Malaysia, the Philippines, Thailand, and Singapore.

11 The European Union is United Kingdom, Germany, the Netherlands, France, Italy, Belgium, Luxembourg, Denmark, Ireland, Greece, Spain, Portugal, Austria, Finland, Sweden, and other countries in union.

12 Trade direction accounted is also including Hong Kong and China Taipei into RRC. 
4. International reserve minus gold (in million dollars) as one economic criterion to for the weigh of each observable currency in the basket. The data span from 2004 to 2010 on yearly basis.

5. Baht against US dollar (USD/THB), rupiah against dollar (USD/IDR), ringgit against dollar (USD/MYR), peso against dollar (USD/PHP), and Singapore dollar against dollar (USD/SGD). The data spans from 2004 to 2010 on daily basis.

6. IDR $13 / A E R U, M Y R / A E R U$, PHPIAERU, THBIAERU, SGD/AERU. All data spans from January, 022004 to October, 212011 on daily basis.

7. US\$-EurO/AERU is defined as the value of the AERU in terms of a weighed average of the US dollar and the euro. The data spans from January, 022004 to October, 212011 on daily basis.

8. US\$-Euro-Yen-Yuan/AERU is defined as the value of the AERU in terms of a weighed average of the US dollar, the euro, the yen, and the yuan. The data spans from January, 022004 to October, 212011 on daily basis.

9. US\$-Euro-Yen/AERU is defined as the value of the AERU in terms of a weighed average of the US dollar, the euro, and the yen. The data spans from January, 022004 to October, 212011 on daily basis.

10. The rate of USD, Euro, Yen, Yuan and Singapore dollar against hypothetical $A E R U$, defined as the value of the AERU in terms of a weighed average of these currencies. The data ranges from January, 022004 to October, 212011 on daily basis.

All data are obtained from International Financial Statistics (IFS), Bank Indonesia (BI), Bank Negara Malaysia (BNM), Bank of Thailand (BOT), Central Bank of the Philippines (CBP), Monetary Authority of Singapore (MAS), and PACIFIC Exchange Rate Services.

\section{The Evaluation in Adopting Monetary Cooperation Proposal in ASEAN-5 Countries}

When decision is made to seta new currency then one needs to select an anchor, either single or a basket of currencies. The choice depends not only on trade flows but also on the dominance of the dollar in international trade, finance, and in the pricing of commodities. The selected anchor must have high credibility in the presence of high capital mobility; therefore the link is not subject to speculative attacks.

There are some issues associated with the use of the AERU as a divergence indicator and an instrument for policy coordination. The first is that the regional countries should establish consensus on technical issues including the assignment of currency weighs, the base year

13 IDR = Indonesian Rupiah; MYR = Malaysian Ringgit; PHP = Philippines Peso; THB = Thailand Bath; SGD = Singapore Dollar. 
selection, the grouping of currencies, and period of weigh revision. They have to be set correctly in order to resolve the asymmetry problem. For instance, the smaller the currency weigh, the larger the exchange rate fluctuation of a particular country against AERU will be; therefore the higher the intervention burden will be (Moon, et al. 2006). Later Moon, et al (2006) suggest that regional monetary authorities should provide weighs using the combination of GDP based on PPP-value, intraregional trade, and contribution to regional monetary and financial cooperation (e,g., Chiang Mai contribution). In addition, Ogawa and Shimizu (2005) proposed the following basket weighs of AERU, which were adopted from ECU:

1. Trade volume is calculated as a total of export and import volumes from the direction of trade statistics, and central bank of each ASEAN-5 countries.

2. Nominal GDP.

3. GDP measured at Purchasing Power Parity (PPP) is used because the nominal GDP does not always reflect international differences in relative prices.

4. International reserve (minus gold) as indicators of basket weighs from a viewpoint of financial aspect comparison.

The proposed currency union is hopefully able to adopt the precedent and un-precedent pressure into a currency union. For such purpose, the coming established currency union has to be able to maintain their stability and volatility over various periods or we can call them as normal and crisis periods. Since the periods of observations range from 2004 to 2010, we divide them into two circumstances based on the standard deviation for normal period as well as for crisis period.

Another important technical issue in forming the AERU index is the choice of base year to calculate the exchange rate benchmark ${ }^{14}$. One of the most popular ways is to choose the year when a fundamental equilibrium of both internal and external sectors is achieved. In other words, the base year is chosen when the total international transaction of the country members countries close to being balanced. On this paper, we use the balance of trade (in US dollars) of ASEAN-5 countries against several combination of the following trading partner: US, EU, Japan, China, and Singapore. The yearly data observed spans from the year 2004 to 2010.

The second consideration is the variety of exchange rate systems. Different exchange rate systems among the countries can distort the role of AERU as divergence indicator. Without an appropriate mechanism to reflect this exchange rate systems differences, the divergence indicator may not function properly as a surveillance mechanism. Currently, many ASEAN-5 countries are still using the US dollar as their anchor. The possible suggestion is that the anchor currency should reflect the trade volume of the main trade partner, therefore will consists of hard currencies, such as Singapore dollar.

14 The chosen year based on internal and external equilibrium of trade takes an assumption that a one-year time lag before changes in exchange rates might affect trade volumes. The exchange rate of the AERU in terms of various currency baskets is set unity for the base year. 
Watanabe and Ogura (2006) have studied on the Regional Monetary unit (RMU). However, given that a currency union takes long process to be realized, they propose to create AERU. Eichengreen (2006) calls this a parallel currency approach. The present paper considers the method of Ogawa and Shimizu (2005), which follows the same principle of the European Currency Unit under the EMS, which is, computed as the weighed average of each country's currency within the region. In the same way that the ECU was defined as a basket of currencies of EU member countries, the AERU is defined as a basket currency of the ASEAN-5 (Indonesia, Malaysia, the Philippines, Singapore, and Thailand).

\section{Calculation Steps}

According to Ogawa and Shimizu (2005), for the benchmark period, the exchange rate of the AERU in terms of various baskets arrangement is set at unity. Setting for unity implies that a weighed trade proportion is set on a hundred percent for each benchmark calculation separately. Then, several steps are incorporated into calculation as follows:

\section{Step 1: Determining the AERU Weights}

As mentioned previously, that this paper compares four different economic size indicators and then tries to select which two out of four indicators has the highest stability when each of them is applied on every single currency basket observed ${ }^{15}$, either in normal or crisis period.

Generally, the weigh of the basket is supposed to represent the weigh of the country's economic importance and contribution to economic cooperation in the region. Following Ogawa and Shimizu (2005), we use four different economic size indicators ${ }^{16}$, then calculate the optimal share weighs ${ }^{17}$ for the last three or four years. Since the present paper is comparing the best currency peg for ASEAN-5, the normal period and crisis period is set separately by taking three years average of normal period ${ }^{18}$ (2004-2006) and four years average of crisis period ${ }^{19}$ (2007-2010).

The AERU weigh for each ASEAN-5 currency = Average Benchmark Exchange Rate for each ASEAN-5 country based on the each observable currency basket $X$ economic size indicator $^{20}$.

15 We observe eights different basket currencies, namely (1) US\$-Euro, (2) US\$-Euro-Yen-Yuan, (3) US\$-Euro-Yen, (4) US\$, (5) Euro, (6) Yen, (7) Yuan, (8) Singapore Dollar.

16 They used 1) trade volume; 2) Nominal GDP; 3) GDP measured at Purchasing Power parity; 4) International Reserves (minus Gold). From the stand point of stability vis-à-vis the US\$-Euro basket currency, the PPP measured GDP and trade volume were chosen as weights.

17 It is calculated by comparing the standard deviation of each the value of AERU in terms of a weighted average the numerous exchange rate regimes. Then, the two lowest of economic size indicators are incorporated by computing theirs arithmetic shares for normal as well as crisis period separately.

18 Three years for normal are determined by considering one year before and after the year of normal period, which is set in 2005 for ASEAN-5 national currencies against US dollar.

19 Three years for crisis are determined by considering one year before and after the year of crisis period, which is set in 2008 for ASEAN-5 national currencies against US dollar.

20 See Ogawa and Shimizu (2005). 
For example, the AERU weigh in terms of US\$-Euro/AERU for IDR = Average benchmark for IDR in terms of US\$-Euro X trade volume. We then can call it as the IDR weigh in terms of US\$-Euro.

\section{Step 2: Calculating the benchmark exchange rate for each ASEAN-5 currency in terms of proposed currency baskets ${ }^{21}$}

Benchmark ${ }^{22}$ exchange rate calculation for each ASEAN-5 currency in terms of (US\$Euro/AERU) = average of ((USD/Each ASEAN-5 Currency $X$ a weighed trade proportion ${ }^{23}$ with US) + (EURO/Each ASEAN-5 Currency $X$ a weighed trade proportion with European Union)).

For example: Benchmark of IDR for US\$-Euro/AERU = average of ((USD/IDR X 58\%) + (Euro/IDR $\times 42 \%)$ ).

\section{Step 3: Calculating and selecting the anchor for ASEAN-5 monetary union}

The value of AERU in terms of a weighed average of the US dollar and the Euro (US\$-Euro/ AERU) is calculated as follows:

US\$-Euro/AERU ${ }^{24}=((I D R$ weigh $) *(U S \$-E u r o / I D R))+((M Y R$ weigh $) *(U S \$-E u r O / M Y R)+$ $((P H P$ weigh $) *(U S \$$-Euro/PHP $))+((T H B$ weigh $) *(U S \$-E u r O / T H B))+((S G D$ weigh $) *(U S \$-$ Euro/SGD) $)^{25}$

\section{Step 4 :Measuring the Volatility Performance over Numerous AERU Arrangements}

The less volatility of AERU against selected currencies basket is better alternative for providing the best anchor in pursuing the optimum currency area criteria. An OCA criterion is maintaining the exchange rate stability stipulated in the Maastricht Treatyof plus minus 15 percent from central parity.

21 The same formula is applied for other currency arrangements, namely (1) US\$-Euro-Yen-Yuan/AERU, (2) US\$-Euro-Yen/AERU, (3) US\$/AERU, (4) Euro/AERU, (5) Yen/AERU, (6) Yuan/AERU, (7) Singapore dollar/AERU.

22 The benchmark period refers to the year which the total international transaction of the members countries are as close to being balanced as possible and their balances with the rest of the world are also small as possible. The base year calculation uses the balance of Trade (exports volume minus imports volume in US dollars) of ASEAN-5 countries (1) within ASEAN-5 countries, (2) with US, EU, Japan, and China, (3) with US, EU, and Japan, (4) with US and EU, (5) with US, (6) with EU, (7) with Japan, (8) with China, and (9) with Singapore. The result is 2007 and 2008.

23 It is accounted from the proportion of balance of trade of ASEAN-5 over the several countries trade partners in percentage point, namely the proportion of ASEAN-5 balanced trade (1) with US, EU, Japan, and China, (2) with US, EU, and Japan, (3) with US and EU.

24 AERU represents Indonesian Rupiah (IDR), Malaysian Ringgit (MYR), the Philippines Peso (PHP), Thailand Bath (THB), and Singapore Dollar (SGD).

25 The same formula is applied for other currency arrangements, namely (1) US\$-Euro-Yen-Yuan/AERU, (2) US\$-Euro-Yen/AERU, (3) US\$/AERU, (4) Euro/AERU, (5) Yen/AERU, (6) Yuan/AERU, (7) Singapore dollar/AERU. 
In the literature, different approaches for measuring exchange rate volatility have been applied, however there is no consensus on which measure is the most appropriate. Usually, the average absolute difference between the previous period forward rate and the current spot rate is considered to be the best indicator of the exchange rate volatility. The present paper follows Ogawa and Shimizu (2006) to measure on exchange rate volatility, namely nominal deviation indicator (NDI). It indicates how far each ASEAN-5 currency deviates from the benchmark exchange rate in terms of the AERU. The nominal AERU deviation indicator is calculated as follows:

Nominal Deviation Indicator $(\%)=$ $\left(\frac{\text { Actual exchange rate of } A E R U}{a \text { currency }}\right)-\left(\frac{\text { benchmark exchange rate of } A E R U}{a \text { currency }}\right)$ $\left(\frac{\text { benchmark exchange rate of } A E R U}{\text { a currency }}\right)$

Furthermore, this paper proposes the criteria as the threshold to categorize the degree of volatility into low, medium and high volatility. The optimal threshold is set to resolve the asymmetry problem and to strengthen symmetry policy response among member countries. Moon (2006) suggests that the smaller currency weigh of a country is, the larger the exchange rate fluctuation of the country against the AERU will be, vice versa. He later suggests that every country weigh should be not more than 0.33 to maintain national currency stability against currency union. Therefore, the upper limit to be agreed upon is 0.33 in order to limit the overwhelming fluctuation in a currency union. The measurement of volatility is covering AERU against basket currencies as well as AERU against ASEAN-5 currencies, respectively. In addition, to categorize the degree of volatility among ASEAN-5 currencies and common basket currencies against AERU, the rules below are set as follows:

1. If the number of nominal deviation exceeds the allowed bands ${ }^{26}$ and the average number of nominal deviation is within 0.67 - 1, it is categorized as having high level of volatility.

2. If the number of nominal deviation exceeds the allowed bands and the average number of nominal deviation is between $0.34-0.66$, it reflects medium level of volatility.

3. If the number of nominal deviation exceeds the allowed bands and the average number of nominal deviation is within $0-0.33$, it indicates as low level of volatility.

\section{Step 5 :Assesment of participation in AERU based on ERM II}

Assesment of participation is set to provide a more published picture about exchange rate volatility and more serious data base for assessment as stated in Maastrcht Treaty. As stipulated

26 The threshold is calculated from plus minus 15 percent (ERM II) of nominal deviation indicator for normal period and crisis period. 
in the Maastricht, exchange rate stability would have to be fulfilled by member state for at least recent two years and has not undergone devaluation.

For such reason, the simulation participation which is formatted based on the most stable basket currency against AERU for ASEAN-5 countries. The upper and lower band are set by multiplying plus and minus 15 percent towards each benchmark currencies of each ASEAN-5 currency against AERU, both in normal and crisis periods. For normal period, the range is set from January 2004 to December 2005 on daily basis, while for the crisis period, the range spans from January 2008 to December 2009 on daily basis.

Technically, to assess the participation criteria among ASEAN-5 countries under AERU arrangement, the paper utilizes average exchange rate movement (AERM), average number fluctuation within bands (ANFB), average number volatility (ANV), standard deviation exchange rate movement (SERM), and level of volatility (LV). All of those measurements would generate a conclusion on the exchange rate stability decision. In addition, the exchange rate stability decision is based on the rule set by nominal deviation in step 4.

\section{RESULT AND ANALYSIS}

\section{Descriptive Assesment for Monetary Union in ASEAN-5 Countries}

A descriptive assessment on asymmetric shock shows the possibility of ASEAN-5 to form a union. Overall, either supply and demand shocks seem similar, even though for Indonesia, they are relatively lower compared to the rest of the countries. In other words, the degree of symmetric shocks in AEAN-5 is compatible to proceed, considering the Euro zone shocks which appears to be only slightly lower27.

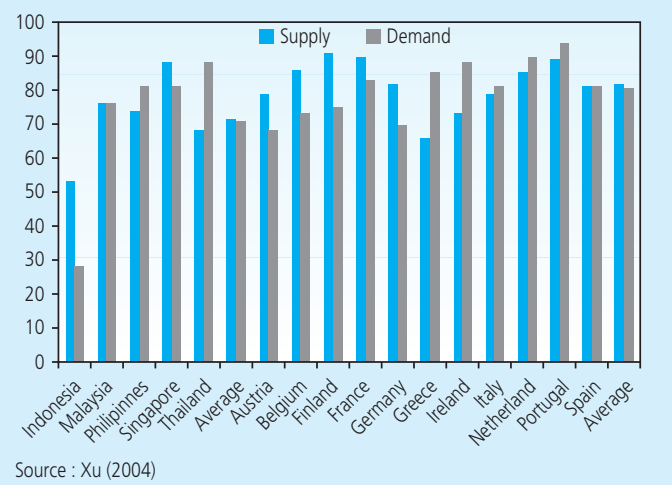

Figure 1.

Symmetry of Demand and Supply Shocks in ASEAN-5 and EURO Zone

27 Indonesia is an outlier whose demand and supply shocks do not seem to be well synchronized with the rest of ASEAN countries. 
In addition, this assessment is in line with many literatures that ASEAN-5 countries do not experience many asymmetric shocks. See for instance, Xu (2004) who computed the percentage of the variation in demand and supply shocks that can be attributed to common shocks. Following Blanchard-Quah, he applied structural VAR procedure and factor analysis to identify the supply and demand shocks, and then estimates the common component of these shocks ${ }^{28}$. The share of the total variation captured by this common component can be interpreted as expressing the degree of symmetry in the shocks. Therefore, ASEAN- 5 are eligible to create an union based on the degree of similarity, and integration in terms of their economic structure which provide symmetric shocks.

\section{The Weigh and Benchmark Exchange Rate Calculation}

This part covers the firstand the second step as outlined before, namely (i) determining the AERU weights, and (ii) calculating the benchmark exchange ratefor each ASEAN-5 currencies in terms of proposed currency basket.

On addressing the weighs on each currency basket, the value of AERU would have been shared into several currencies. The shared average of particularly common basket currency is based on important trading partners with ASEAN-5 countries. As the common basket currency is quoted in terms of a shared average of the US\$-Euro, the US\$-Euro-Yen-Yuan, the US\$Euro-Yen, and some individual basket currencies, the shares on those basket currencies are set at unity.

\begin{tabular}{|c|c|c|c|c|c|}
\hline \multicolumn{6}{|c|}{$\begin{array}{c}\text { Table } 6 . \\
\text { The Shares on the Basket Currency (\%) in AERU Arrangement }\end{array}$} \\
\hline Basket Currency & US\$ & Euro & Yen & Yuan & SGD \\
\hline US\$-Euro & 58 & 42 & - & - & - \\
\hline US\$-Euro-Yen-Yuan & 22 & 22 & 20 & 36 & - \\
\hline US\$-Euro-Yen & 34 & 35 & 31 & - & - \\
\hline US\$ & 100 & - & - & - & - \\
\hline Euro & - & 100 & - & - & - \\
\hline Yen & - & - & 100 & - & - \\
\hline Yuan & - & - & - & 100 & - \\
\hline Singapore Dollar & - & - & - & - & 100 \\
\hline
\end{tabular}

On calculating the countries' shares over various economic size indicators, we use the four distinct economic size indicators to determine the best weighs. This weigh will influence the amount of convertion rate for each national currency.

28 This approach is widely used, but is subject to an important criticism. This is that the shocks identified as demand shocks are in fact temporary shocks, while the shocks identified as supply shocks are in fact permanent shocks. 


\begin{tabular}{|c|c|c|c|c|c|c|c|c|c|c|}
\hline \multicolumn{11}{|c|}{$\begin{array}{l}\text { Table } 7 \text {. } \\
\text { The Country Share for ASEAN-5 Weighs }\end{array}$} \\
\hline \multirow{2}{*}{$\begin{array}{l}\text { Economic Size } \\
\text { Indicators }\end{array}$} & \multicolumn{2}{|c|}{ Indonesia } & \multicolumn{2}{|c|}{ Malaysia } & \multicolumn{2}{|c|}{ The Philippines } & \multicolumn{2}{|c|}{ Thailand } & \multicolumn{2}{|c|}{ Singapore } \\
\hline & $\mathbf{N}$ & C & $\mathbf{N}$ & C & $\mathbf{N}$ & C & $\mathbf{N}$ & C & $\mathbf{N}$ & C \\
\hline Trade Volume & 8.18 & 10.17 & 17.78 & 19.03 & 4.44 & 4.82 & 10.50 & 12.26 & 59.09 & 53.72 \\
\hline Nominal GDP & 35.76 & 39.32 & 16.53 & 15.02 & 11.96 & 11.98 & 21.45 & 20.15 & 14.30 & 13.54 \\
\hline GDP measured at PPP & 34.25 & 31.10 & 21.77 & 21.78 & 3.92 & 4.37 & 17.72 & 18.51 & 22.34 & 24.24 \\
\hline $\begin{array}{l}\text { International Reserve } \\
\text { (Minus Gold) }\end{array}$ & 12.06 & 12.82 & 24.05 & 18.61 & 5.42 & 8.31 & 18.18 & 24.22 & 40.29 & 36.05 \\
\hline
\end{tabular}

Table 7 shows that Indonesia has the highest shares in terms of nominal GDP and GDP measured at purchasing power parity (PPP). In contrast, Singapore records the highest shares in terms of trade volume and international reserve (minus Gold), either in normal or crisis period. Among the rest, the Philippines is accounted for the lowest shares over the four various economic size indicators.

The benchmark period is chosen in order to calculate the benchmark exchange rate. The benchmark period is defined when the total balance of trade of ASEAN-5 is relatively close to zerowith the following trading partner: within ASEAN-5; with US, EU, Japan, and China; with US, EU, and Japan; with US and EU; with US; with EU; with Japan; with China; with Singapore. The table 8 shows the balance of trade of the ASEAN-5 from 2004 to 2010. It shows that 2008 is the year which majority of the balance of trade is close to zero. The purpose under such rule mentioned by De Grauwe (2007) is that the countries under monetary union will be able to pay their debts without creating surprise inflation and or devaluation, which reduces the real value of the debts, but increase its nominal value and downgrade government credibility. The absence of trade deficits is the indicator to show their commitments to preserve the union from defaults.

\begin{tabular}{|c|c|c|c|c|c|c|c|c|c|}
\hline \multicolumn{10}{|c|}{$\begin{array}{l}\text { Table } 8 \text {. } \\
\text { Balance of Trade of ASEAN-5 against selected Trading Partner }\end{array}$} \\
\hline Year & ASEAN & $\begin{array}{c}\text { AS, UE, } \\
\text { Japan, } \\
\text { and China }\end{array}$ & $\begin{array}{l}\text { AS, UE, } \\
\text { and } \\
\text { Japan }\end{array}$ & $\begin{array}{l}\text { AS } \\
\text { and UE }\end{array}$ & AS & UE & Japan & China & Singapore \\
\hline 2004 & 8.03 & 36.18 & 15.00 & 27.28 & 15.54 & 11.74 & -12.27 & 3.08 & 9.59 \\
\hline 2005 & 34.72 & 77.34 & 15.18 & 41.26 & 22.11 & 19.15 & -26.08 & 23.49 & 9.91 \\
\hline 2006 & 34.31 & 96.31 & 21.78 & 41.01 & 19.65 & 21.36 & -19.22 & 26.37 & 10.87 \\
\hline 2007 & 43.06 & 77.12 & 15.73 & 31.00 & 13.56 & 17.44 & -23.27 & 30.89 & 8.99 \\
\hline 2008 & 27.09 & -52.58 & -7.43 & -0.26 & -1.26 & 1.00 & -14.18 & -30.89 & 7.52 \\
\hline 2009 & 30.44 & 53.51 & -18.51 & -0.80 & -2.42 & 1.62 & -17.71 & 45.27 & 8.36 \\
\hline 2010 & 39.77 & 78.89 & -22.47 & 5.50 & -4.55 & 10.05 & -27.97 & 61.91 & 10.23 \\
\hline
\end{tabular}


Assuming a one-year time lag before changes in exchange rates affect trade volumes, we should select 2007 and 2008 as the benchmark periods.

The benchmark exchange rate is calculated separately for each ASEAN-5 country in terms of the AERU. The benchmark for normal and crisis period is not different. The use of the benchmark is to calculate the conversion of each ASEAN-5 national currency against AERU (with various proposed basket currency, including for commodity peg currency). The calculation result is presented below.

\begin{tabular}{|c|c|c|c|c|c|c|}
\hline \multicolumn{7}{|c|}{$\begin{array}{l}\text { Table } 9 . \\
\text { The Benchmark Exchange Rate of each ASEAN-5 in terms of AERU }\end{array}$} \\
\hline No & AERU/Country & Indonesia (IDR) & Malaysia (MYR) & $\begin{array}{l}\text { The Phillipines } \\
\text { (PHP) }\end{array}$ & $\begin{array}{l}\text { Thailand } \\
\text { (THB) }\end{array}$ & $\begin{array}{l}\text { Singapore } \\
\text { (SGD) }\end{array}$ \\
\hline 1 & US\$-Euro/AERU & $9.38728 \times 10^{-5}$ & 0.25978 & 0.01946 & 0.02695 & 0.60204 \\
\hline 2 & $\begin{array}{l}\text { US\$-Euro-Yen- } \\
\text { Yuan/AERU }\end{array}$ & 0.00269 & 7.44227 & 0.55644 & 0.77286 & 17.22865 \\
\hline 3 & US\$-Euro-Yen/AERU & 0.00375 & 10.33370 & 0.77262 & 1.07316 & 23.92139 \\
\hline 4 & US\$/AERU & 0.00011 & 0.29646 & 0.02217 & 0.03074 & 0.68715 \\
\hline 5 & Euro/AERU & 0.00008 & 0.20913 & 0.01562 & 0.02171 & 0.48450 \\
\hline 6 & Yen/AERU & 0.01188 & 32.77326 & 2.45036 & 3.40357 & 75.86513 \\
\hline 7 & Yuan/AERU & 0.00078 & 2.15664 & 0.16125 & 0.22390 & 4.99405 \\
\hline 8 & SGD/AERU & 0.00016 & 0.43252 & 0.03233 & 0.04489 & 0.68715 \\
\hline
\end{tabular}

According to table 9, benchmark of IDR is the smallest against AERU for every currency basket. On the other hand, SGD shows the biggest value of benchmark against AERU. These imply that the value of IDR in every basket currency must be the highest, and SGD is viceversa.

Selecting the most stable among the four types of indicators is based on the lowest standard deviation in terms of rate of change (\%). Therefore, the use of statistical measurement in rates of change (\%) can captures the stability of ASEAN-5 currency against AERU (Ogawa Shimizu, 2005). Following Ogawa and Shimizu work (2005), we will take two most stable types of AERU and use them to calculate the weighs of currency basket in AERU for ASEAN-5 currencies.

Table 10 provides the summary of selected best indicators over various currency baskets against AERU. The results shows that the nominal GDP and GDP measured at PPP are the most stable indicators across proposed currency baskets, either under normal and crisis periods. GDP, either nominal or real, is the best indicators as weigh since in a monetary union a country needs strong economic structures, accompanied by a credible macroeconomic policies, which lead to structural convergence. 


\begin{tabular}{|c|c|c|c|}
\hline \multicolumn{4}{|c|}{$\begin{array}{l}\text { Table } 10 . \\
\text { Selected Economic Size Indicators over various Currency Baskets under Normal and Crisis Period }\end{array}$} \\
\hline \multirow{2}{*}{ No } & \multirow{2}{*}{ Currency Basket } & \multicolumn{2}{|c|}{ Economic Size Indicator } \\
\hline & & Normal & Crisis \\
\hline 1 & US\$-Euro & $\begin{array}{l}\text { Trade Volume and International } \\
\text { Reserve }\end{array}$ & $\begin{array}{l}\text { Trade Volume and International } \\
\text { Reserve }\end{array}$ \\
\hline 2 & US\$-Euro-Yen-Yuan & $\begin{array}{l}\text { Nominal GDP and GDP Measured at } \\
\text { PPP }\end{array}$ & $\begin{array}{l}\text { Nominal GDP and GDP Measured at } \\
\text { PPP }\end{array}$ \\
\hline 3 & US\$-Euro-Yen & $\begin{array}{l}\text { Nominal GDP and GDP Measured at } \\
\text { PPP }\end{array}$ & $\begin{array}{l}\text { Nominal GDP and GDP Measured at } \\
\text { PPP }\end{array}$ \\
\hline 4 & US\$ & $\begin{array}{l}\text { Trade Volume and International } \\
\text { Reserve }\end{array}$ & $\begin{array}{l}\text { Trade Volume and International } \\
\text { Reserve }\end{array}$ \\
\hline 5 & Euro & $\begin{array}{l}\text { Nominal GDP and GDP Measured at } \\
\text { PPP }\end{array}$ & $\begin{array}{l}\text { Nominal GDP and GDP Measured at } \\
\text { PPP }\end{array}$ \\
\hline 6 & Yen & $\begin{array}{l}\text { Nominal GDP and GDP Measured at } \\
\text { PPP }\end{array}$ & $\begin{array}{l}\text { GDP measured at PPP and } \\
\text { International Reserve }\end{array}$ \\
\hline 7 & Yuan & $\begin{array}{l}\text { GDP measured at PPP and Trade } \\
\text { Volume }\end{array}$ & $\begin{array}{l}\text { GDP measured at PPP and } \\
\text { International Reserve }\end{array}$ \\
\hline 8 & Singapore Dollar & Trade Volume and Nominal GDP & Trade Volume and Nominal GDP \\
\hline
\end{tabular}

\section{Choosing the anchorover numerous AERU arrangements}

This part covers the third and the fourth of calculation step outlined before, namely the calculation of ancor currencies for ASEAN-5 monetary union, and measuring the volatility performance over numerous AERU arrangements. The nominal deviation indicator (NDI) is exercised to measure the degree of volatility of currency basket alternatives. The results is presented in Table 11, both for normal and crisis periods.

\begin{tabular}{|c|c|c|c|}
\hline \multicolumn{4}{|c|}{$\begin{array}{l}\text { Table } 11 . \\
\text { Exchange Rates Volatility against AERU based on Nominal Deviation }\end{array}$} \\
\hline \multicolumn{4}{|c|}{ Number of Volatility on Various Currency Baskets Arrangements } \\
\hline Average & Normal & Crisis & Average \\
\hline U.S.\$-euro/AERU & 0.38 & 0.61 & 0.495 \\
\hline U.S.\$-euro-Yen-Yuan/AERU & 0.38 & 0.57 & 0.475 \\
\hline U.S.\$-euro-Yen/AERU & 0.65 & 0.59 & 0.62 \\
\hline U.S.\$IAERU & 0.42 & 0.02 & 0.22 \\
\hline euro/AERU & 0.01 & 0.04 & 0.025 \\
\hline Yen/AERU & 0.43 & 0.60 & 0.515 \\
\hline Yuan/AERU & 0.00 & 0.02 & 0.01 \\
\hline SGD/AERU & 0.08 & 0.02 & 0.05 \\
\hline
\end{tabular}


Overall, the selected currencies are fluctuating during the two separated condition. It is evident that Yuan is the most stable currencies throughout the observation, both in crisis and normal period, with average volatility of 0.01 . This leads us to choose Chinese Yuan as the currency anchor for AERU arrangement within ASEAN-5 countries.

Beside NDI indicator, we also consider the average and the standard deviation of band fluctuation ${ }^{29}$. Empirically, table 12 shows the summary of currency movement over various currency baskets, either normal and crisis periods. In general, all ASEAN-5 currencies are moving or fluctuating against selected exchange rate arrangements under AERU. During normal period, interestingly all ASEAN-5 currencies tend to depreciate against selected currency arrangements under AERU calculation.

This depreciation occurs under normal period in which during this period, all ASEAN-5 countries were promoting their export and benefited from existing depreciation. Differently, during crisis period, depreciation occurred when the ASEAN-5 countries pegged to US\$-EuroYen, Yen, Yuan, and Singapore Dollar (SGD). Those currencies are not source of current global financial crisis and so much relies upon their economy on trade. Such that, once ASEAN-5 pegged to those currencies, ASEAN-5 economies are attempting to boost their exports and reduce their volume of imports which are needed to underpin the trade balance policy in the mid of crisis. In addition, under AERU framework, ASEAN-5 economies are yet buffering their economy by compounding their money supply, even though could elevate inflation rate.

\begin{tabular}{|c|c|c|c|}
\hline \multicolumn{4}{|c|}{$\begin{array}{c}\text { Table } 12 . \\
\text { Currency Movement over Various Currency Basket under Normal and Crisis Periods }\end{array}$} \\
\hline \multirow{2}{*}{ No } & \multirow{2}{*}{ Currency Baskets } & \multicolumn{2}{|c|}{ Average Fluctuations Band } \\
\hline & & Normal & Crisis \\
\hline 1 & US\$-Euro/AERU & $\begin{array}{l}\text { All currencies depreciate, except for } \\
\text { Indonesia }\end{array}$ & All currencies appreciate \\
\hline 2 & US\$-Euro-Yen-Yuan/AERU & $\begin{array}{l}\text { All currencies depreciate, except for } \\
\text { Indonesia }\end{array}$ & $\begin{array}{l}\text { All currencies appreciate, except for } \\
\text { Malaysia and Singapore }\end{array}$ \\
\hline 3 & US\$-Euro-Yen/AERU & $\begin{array}{l}\text { All currencies depreciate, except for } \\
\text { Indonesia, and Philippines }\end{array}$ & All currencies depreciate \\
\hline 4 & US\$/AERU & $\begin{array}{l}\text { All currencies depreciate, except for } \\
\text { Indonesia }\end{array}$ & $\begin{array}{l}\text { All currencies appreciate, except for } \\
\text { Indonesia and Philippines }\end{array}$ \\
\hline 5 & Euro/AERU & $\begin{array}{l}\text { All currencies appreciate, except for } \\
\text { Philippines }\end{array}$ & All currencies appreciate \\
\hline 6 & Yen/AERU & $\begin{array}{l}\text { All currencies depreciate, except for } \\
\text { Indonesia }\end{array}$ & All currencies depreciate \\
\hline 7 & Yuan/AERU & $\begin{array}{l}\text { All currencies depreciate, except for } \\
\text { Indonesia, and Malaysia }\end{array}$ & All currencies depreciate \\
\hline 8 & SGD/AERU & $\begin{array}{l}\text { All currencies depreciate, except for } \\
\text { Indonesia, and Malaysia }\end{array}$ & $\begin{array}{l}\text { All currencies depreciate, except for } \\
\text { Indonesia }\end{array}$ \\
\hline
\end{tabular}

29 The former and latter is calculated by taking average and standard deviation on exchange rate deviation from benchmark exchange rate over period of observations. 
In brief, under monetary union or AERU framework, ASEAN-5 economies remain fragile for instability unless they keep strengthening coordination on their exchange rate management. Meanwhile, ASEAN-5 currencies tends to appreciate against US\$-Euro, US\$-Euro-Yen-Yuan, US\$, and Euro. This is in line with the current situation in Europe and US economies. Under AERU, ASEAN-5 countries realized that holding risky currencies may eventually transmit their crisis into ASEAN-5 economies. Moreover, during crisis, US and European countries called back their currencies in order to reduce their money supply all over the globe and reduced their inflation rates. In other words, under AERU, member states should pegged the currencies to credible and economically sound currency to avoid the union being trapped into the same crisis or financial instability.

\section{Assessment of Participation in AERU Based on ERM II}

This section covers the fifth step where we will asses the participation of each ASEAN-5 member in AERU. From the previous section, we have acknowledged Chinese Yuan as the currency anchor for AERU, since it is the most stable currency peg. Now we can proceed to establish assessment criteria which allowus to propose the country member of the OCA. The assesment is developed for a period of 2 years and the margin set is plus and minus 15 percent from the AERU conversion rate (as benchmark) in terms of Chinese Yuan for five currencies, both in normal and crisis periods.

The test for a 2 years period refers to participation criteria fulfillment condition in the EU, which is extended on the present study into two different condition; normal and crisis. As noted earlier, normal period is 2004-2006, and crisis period is 2007-2010. Thus, the assessment on exchange rate stability is conducted 2 years before the currency union implementation. For normal period, its implementation will be in 2006, so that the assessment criterion becomes 2004-2005. Similarly for crisis period, 2008-2009 becomes subject to assessment since policy makers agree to implement the currency union in 2010.

Table 13 shows the statistical evaluation of simulation of ERM II for ASEAN-5 currencies in terms of Yuan. According to AERM statistical calculation, ASEAN-5 currencies against AERU depreciate during crisis period compared with normal period, except for Malaysian ringgit and Singapore dollar. Meanwhile, based on SERM, during crisis period, the standard deviation for ASEAN-5 currencies has bigger dispersion than in normal period, except for Malaysian ringgit and Singapore dollar which remain constant. Then, the ANF results outline that all ASEAN-5 currencies are having low volatility, either in normal or crisis period, except for Indonesian rupiah in crisis period. However, all in all, ASEAN-5 currencies against AERU have shown that under Yuan currency basket peg, the exchange rate stability will have to be in place once ASEAN-5 countries agree to join a currency union. 
Table 13.

Simulation of ERM II Participation in terms of Chinese Yuan for ASEAN-5 Currencies

Statistical Figures

\begin{tabular}{|c|c|c|c|c|c|c|c|c|c|c|}
\hline \multirow{2}{*}{ Exchange rate } & \multicolumn{2}{|c|}{ AERM* } & \multicolumn{2}{|c|}{ SERM $^{* * * *}$} & \multicolumn{2}{|c|}{ ANFB** } & \multicolumn{2}{|c|}{$\mathrm{ANF}^{* * *}$} & \multicolumn{2}{|c|}{$\mathbf{L V}^{* * * * *}$} \\
\hline & $\mathbf{N}$ & C & $\mathbf{N}$ & C & $\mathbf{N}$ & C & $\mathbf{N}$ & C & $\mathbf{N}$ & C \\
\hline IDR/AERU & 240.19 & 251.01 & 15.31 & 24.80 & 0.76 & 0.63 & 0.24 & 0.37 & Rendah & medium \\
\hline MYR/AERU & 0.09 & 0.08 & 0.00 & 0.00 & 1.00 & 0.95 & 0.00 & 0.05 & Rendah & Rendah \\
\hline PHPIAERU & 0.29 & 0.38 & 0.00 & 0.03 & 1.00 & 0.94 & 0.00 & 0.06 & Rendah & Rendah \\
\hline THB/AERU & 0.69 & 0.91 & 0.02 & 0.05 & 1.00 & 0.67 & 0.00 & 0.33 & Rendah & Rendah \\
\hline SGD/AERU & 0.08 & 0.06 & 0.00 & 0.00 & 1.00 & 1.00 & 0.00 & 0.00 & Rendah & Rendah \\
\hline
\end{tabular}

The flexible judgment in determining ASEAN-5 participation utilizes the exchange rate stability criteria. Empirically, it is based on the value of AERM, ANFB, ANV, SERM, and LV indicate stability path. The results suggest that all ASEAN-5 countries have low level of volatility, except for Indonesian rupiah, but her volatility is yet considered low, around 0.37 , during crisis period. Therefore, ASEAN-5 countries under Yuan currency basket peg could be considered into optimum currency area (OCA) based on their exchange rate stability criterion. Based on this, we conclude that all ASEAN-5 currencies are eligible to join a currency union against AERU, both using normal period and crisis periods.

The finding is in line with the study conducted by Shirono (2009) which suggested currency unions along with China tend to generate higher average welfare gains for East Asian, including ASEAN countries than currency unions with Japan or the United States. This trend is likely to continue if China's role continues to rise in the regional trade.

However, the current issue arises as the movement of Chinese Yuan is highly pegged to US Dollar and is well-known as a heavily manipulated currency against US dollar. This situation open further research, particularly on how to set a stable currency union in the mid of manipulated exchange rate policies by China's government.

30 AERM is defined as the degree of which exchange rate is fluctuating over the period of observation. The higher number of AERM shows that the national currencies are under pressure or getting shocks.

31 ANFB denotes for the number of data in daily basis where the fluctuated currencies are no longer exceeding the allowed bands, namely plus and minus 15 percents. Hence, the smaller ANFB indicates the national currency is no longer fluctuating sharply due to moving within tolerable bands.

32 ANV represents the number of data in daily basis where are no longer in the allowed bands. Hence, the higher of the number shows that the national currency is increasingly unstable.

33 SERM covers the distance between the value on the specific date and the mean of data observed. It informs that the higher of SERM would lead to instability position on the observed currency.

34 LV demonstrates the degree in which the volatility is well-categorized according to nominal deviation results of each national currency against AERU. The low level of volatility indicates the country satisfies the exchange rate stability criteria and ultimately is eligible as member of union. 
In addition, this finding is also relevant with the growing role of China in global economy. In the context of exchange rate policy, this tren provide opportunity for strengthening economic relationship within ASEAN-5. In addition, choosing Yuan as a common anchor currency by ASEAN-5's is supported by the network effects theory. This theory states that the utility of a consumer on particular good is dependent on the number of other individuals consuming the same good (Katz and Shapiro, 1985). There are two implications for this, first, a minimum level of agents consuming the same good (critical mass) is necessary for the initial adoption of a network good (Farrel and Soloner, 1986); second, the demand for network commodities is associated with a bandwagon effect, i.e. the more individuals use the good, the more incentive for others to also use it. These implications will apply on money as a network good and will led to interesting results in the form of monetary integration.

In reality, the network effect does occur in ASEAN-5 countries on their trade relationship with China. The table below demonstrates the growing importance of China within ASEAN-5 trade direction.

\begin{tabular}{|c|c|c|c|c|}
\hline \multicolumn{5}{|c|}{$\begin{array}{l}\text { Table } 14 . \\
\text { Trade Direction of ASEAN-5 to Selected Countries }\end{array}$} \\
\hline Year & $\%$ AS & $\%$ UE & \% Japan & $\%$ China \\
\hline 2004 & 0.429580185 & 0.324580651 & 0.339329802 & 0.085168966 \\
\hline 2005 & 0.285869864 & 0.247609448 & 0.337241631 & 0.303762319 \\
\hline 2006 & 0.204071132 & 0.221759167 & 0.19961032 & 0.273780021 \\
\hline 2007 & 0.175874178 & 0.226154095 & 0.301730436 & 0.399702163 \\
\hline 2008 & 0.001730258 & -0.013779408 & 0.033312653 & 0.425596744 \\
\hline 2009 & -0.045222707 & 0.030233888 & 0.330888125 & 0.845876944 \\
\hline 2010 & -0.057654647 & 0.127367725 & 0.354465197 & 0.784752119 \\
\hline \multirow[t]{2}{*}{ Average } & 0.142035466 & 0.166275081 & 0.261421837 & 0.445519896 \\
\hline & $14 \%$ & $16 \%$ & $26 \%$ & $44 \%$ \\
\hline
\end{tabular}

Table 14 shows ASEAN-5 countries are dominantly trading with China, around $44 \%$ of the four selected trading partner. Swoboda (1968) argues that if residents of a country can only hold non-interest bearing foreign currency assets, and their revenues or expenditures are at least partly denominated in a foreign currency, and also owing to transaction costs (e.g. brokers' fees, bookkeeping, psychological inconvenience, etc.), then it is profitable for them to hold foreign currency cash balances. Krugman (1980) develops a formal three-country, three-currency model, where the transaction costs decline as the size of the market increases. He shows that only the currency with dominant economy can serve as a vehicle currency. Moreover, once a currency serve as international medium of exchange, its vehicle role becomes self-reinforcing and may persist even when its economic power diminishes. This theoretical view is in line with high penetration of Cina towards ASEAN-5 market. 
On the other hand, China's government keeps trying to postion Yuan as a gold-backed currency ${ }^{35}$, which help it to become major international currency. Many economist realize if China is trying to position the Yuan as the alternative global reserve currency. Currently, China is the sixth largest holder of gold reserves in the world, and officially has of 1,054.1 tones of gold. This is less than half of Euro debtor nation; France and Italy, who have 2,435.4 and $2,451.8$ tons of gold reserve respectively. These arguments support the ASEAN-5 country to peg their currency to Yuan.

\section{CONCLUSION}

The paper measures the degree of volatility among various currency basket arrangements using nominal deviation indicator. By exercising of each ASEAN-5 national currency against AERU which are pegged to various selected currencies, the study reveals that ASEAN-5 currencies are recommended to value the AERU into Yuan to maintain ASEAN-5 currencies' stability. Furthermore, the results show that using Yuan as the anchor currency will smooth the fluctuation bands of plus and minus 15 percent from each ASEAN-5 currency benchmark in terms of AERU. This finding leads us to the conclusion of this paper that ASEAN-5 can form a currency union, which is most suitable to be pegged to Yuan.

This conclusion has several implications for political leadersin this region, first, they should complete the internal market unification in the short run, such as AFTA; second, strengthen the competitiveness on goods and services; third, enhance coordination and surveillance on economic policy; fourth, budgetary adjustments in highly debted or deficit countries; fifth, commit to accelerate the establishment of the ASEAN Monetary Institute (AMI), replicating the European Monetary Institute (EMI), which will be institutionally prepared to be the ASEAN Central Bank (ACB).

35 Turkey and China had signed a trade agreement to only use their currencies in the trade. China has signed up similar agreement with almost all of Asia, Belarus, Argentina, Brazil (The Wall Street Journal). 


\section{REFERENCES}

Achsani, Noer Azam, and Hermanto Siregar, 2010, Classification of the ASEAN+3 Economies Using Fuzzy Clustering Approach.EuroJournals Vol. 39 No. 4, pp. 489-497

Achsani, Noer Azam, and Titis P., 2010, Testing the Feasibility of ASEAN+3 Single Currency Comparing Optimum Currency Area and Clustering Approach. Euro Journals Publishing, Inc Issue 37

Agarwal, Aman, Penm, and Wong, 2004, ASEAN DOLLAR: A common Currency Establishment for Stronger Economic Growth of ASEAN Region. Paper presented at the International Conference on Business, Banking, and Finance: Trinidad and Tobago

Azali, Wong, et.al. 2007, The ASEAN-5 Future Currency: Maastricht Criteria, MPRA Paper No. 10272

Bayoumi and Mauro, 2000, On Regional Monetary Arrangements for ASEAN. Journal of Japanese and International Economics 14, 121-148

Eichengreen, Barry, 2006, Global Imbalances: The Blind men and The Elephant. Brookings Policy Brief 1 (January)

Falianty, Telisa Aulia, 2006, Feasibility of Forming Currency Union in ASEAN-5 Countries. Research Laboratory University of Indonesia: Indonesia

Farrel J., Saloner G., 1986, Installed Base and Compatibility: Innovation, Product Preannouncements, and Predation. American Economic Review;76;940-955

Frankel, Jeffrey, 1999, No Single Currency Regime is right for all countries or at all times. Working paper NBER WP No. 7338.

Frankel and Rose, 1998, The Endogeneity of the Optimum Currency Area Criteria. Economic Journal, Royal Economic Society, Vol.108 (449), pages 1009-25, July

Frankel and Wei, 1994, APEC and other regional economic arrangement in the Pacific. Pacific Basin Working Paper Series 94-04, Federal Reserve bank of San Francisco.

Gross and Thygesen, 1998, European Monetary Integration, from the European Monetary System to Economic and Monetary Union. Harlow Essex/New York, Longman.

Ito, Takatoshi, 2006, On Determinants of the Yen Weigh in the Implicit Basket System in East Asia. RIETI Discussion Paper Series 06-E-020 
Katz M.L, Shapiro C., 1985, Network Externality, Competition, and Comparability. American Economic Review; 75; 424-440

Krugman P., 1980, Vehicle Currencies and the Structure of International Exchange. Journal of money, credit, and banking;12 (3); 513-526

Kuroda and Kawai, 2002, Strengthening Regional Financial Cooperation. Pacific Economic Papers 322, pp. 21-35.

Kusuma, Dimas Bagus, and Arief D.P., 2010, Analysis of Implementation Optimum Currency Area and Its Volatility: Case Study ASEAN-5+3. Bulletin of Monetary Economics and Banking Vol. 13, No. 2

McAleer, M.J. and Nam, J.C.W, 2005, Testing for Cointegration in ASEAN Exchange Rates. Mathematics and Computers in Simulation, 68: pp. 519-527

Moon, et al., 2006, Regional Currency Unit in Asia: Property and Perspective. KIEP Working Paper, 06-03.

Mundell, 1961, "A theory of Optimum Currency Areas", American Economic Review, Vol. 51, p657-665

Ogawa, Eiji, 2006, Adopting a common currency basket arrangement into the "ASEAN plus three". RIETI Discussion paper series 06-E-028

Ogawa, Eiji, and Junko Shimizu, 2006, "A Deviation Measurement for Coordinated Exchange Rate Policies in East Asia," RIETI Discussion paper 2006/01 06-E-002

Ogawa and Ito, 2002, On the Desirability of a regional basket currency arrangement.Journal of the Japanese and International Economies 16:317-34.

Ogawa and Shimizu, 2005a, A deviation measurement for coordinated policies in East Asia. RIETI Discussion Paper Series, 05-E-017.

Ogawa and Shimizu, 2005b, Risk Properties of AMU Denominated Asian Bond. Journal of Asian Economics, Vol. 16, issue 4, 590-611

Ogawa and Yoshimi, 2008, Widening Deviation Among East Asian Currencies. RIETI Discussion paper series 08-E-90.

Swoboda A., 1968, The Euro-Dollar Market: An Interpretation. Essays in International Finance; p.64

Warjiyo, Perry, 2004, Materi Kuliah Ekonomi Keuangan Internasional. Post-Graduate Program, Economic Science, University of Indonesia

Watanabe and Ogura, 2006, How Far a Part are two ACUs from each other?: Asian Currency Unit and Asian Currency Union. Bank of Japan Working Paper Series 
Williamson, John, 2005, A currency Basket for East Asia, not Just China. Institute for International Economics, No. PB05-1

Yuen, Hazel, 1999, Globalization and Single Currency the Prospects of Monetary Integration in East Asia. Paper prepared for conference on "The Challenges of globalization", Bangkok. 